\title{
Investments in Small and Medium Businesses, their Role in the Economy Development of Kosovo
}

\author{
Prof. Ass. Dr. Hamdi Hoti \\ Faculty of Economics, University of Prizren \\ Phd. (c) Rifat Hoxha \\ Faculty of Economics, University of Prizren \\ Phd. (c) Remzi Ahmeti
}

Chairman of Auditing Committee, KRM. Uniteti sh.a. Mitrovicë

\section{Doi:10.5901/ajis.2015.v4n2p461}

\section{Abstract}

\begin{abstract}
Small and medium businesses are playing a very important role in the economy of the country as their development is related directly to economic development. Small and medium businesses (SME) make up about $98 \%$ of all enterprises which have the potential to play an important role in economic growth. This is also common agreement about the important role that SME plays in the number of employees. The main goal of this paper is the diagnosis of the current state of Small and Medium Businesses and to identify the problems, obstacles, and barriers that suffocate the development of their activities, identifying both the needs and demands of the community to improve the situation advancing development processes and the development of positive trends in strategic terms. Research data for this paper will provide the Statistical Office of Kosovo, where they will be informed about the number of these businesses and the flow of the interview that will make a number of SME managers to watch out closely to all the problems that may experience these businesses. This paper will try to give theoretical and practical value and be much more convenient for all managers of SME-s, which are hoping to assist in the ongoing development of their businesses.
\end{abstract}

Keywords: Investment, Business, Management, Economic Development.

\section{Small and Medium Enterprises and Economic Growth}

Small and medium sized economic and social role is very important because of their contribution to the economic operation of the network and the creation of new jobs.

These contributions are valuable in crisis conditions and rising unemployment. In Kosovo, business development contributes to copying the numerous challenges associated with economic development, the effects of inequality, high levels of unemployment, demographic growth and the need for structural and other changes.

Recent theoretical developments in the field of economic growth are based on neoclassical theory Robert Solow and Paul Romer.

The difference between Solow and ROMERI is that the first considers advancements in technology as a result of forces outside the system, while ROMERI insists that economic growth is the result of forces within the economic system, not any outside force (Scribd.com, 2015).

Increasing the number of small businesses within an industry affects economic growth through two channels:

1. Increased competition, which improves economic performance;

2. Increasing competition and increasing the percentage of small businesses in the market.

There is a general consensus that carries out the main burden innovation growth of national economies.

The main stages of innovation are as follows: innovation, development, production, market entry and diffusion.

As small as well as the largest contribute to the process of innovation (Scribd.com, 2015).

But the superiority of these categories of businesses depends on the industry, to which they belong. As in a number of industries, small businesses are more efficient in innovation, and then their impact on economic growth is huge. Small and medium-sized national economy to contribute to solve the problems of employment in the country, 
increasing the General National Product, helping in the development of large businesses and contributing to the country's import and export (KËRÇINI, 2008).

Business Development of Small and Medium (SMBs) in Kosovo, together with the restructuring and privatization of the economy is estimated long as one of the main preconditions to the realization of strategic goals for economic development. workforce.

SMBs in Kosovo are the biggest makers of Gross Domestic Product (GDP), and at the same time employ a large

If we do not go deeper, this is perhaps the most successful development in recent years with us.

This is because one of the main pillars on which should support Kosovo's path to regional and European integration SMBs are strong and healthy.

The development of these businesses in Kosovo offers new employment opportunities that help in reducing the level of unemployment and demographic challenges facing the population, which are growing rapidly.

In addition, the development of these businesses sector contributes to strengthening the competitiveness and productivity, and promotes the growth of total revenues and income per head of population in the country.

This development promotes the structural transformation of the SME sector, due to its connection with innovation and technological development in general.

On the other side, the process contributes to regional and local development and social cohesion, by enabling reduction of inequality, because income growth of a broad segment of the population reinforces the demands for better governance.

These positive developments improve economic and political opportunities, transforming demographic discouraging projects that deepen poverty and instability, the forces that can cause positive changes.

For this reason, in general we can conclude that positively affect SMEs in the main vectors of development in the whole country in general. Therefore, the development of the sector of small and medium businesses is important for Kosovo, especially when you consider that social problems are largely as a consequence of the uneven economic growth.

\section{The Role of Private Sector Development in Reviving the Kosovo Economy}

Kosovo is one of the countries where the transition to a market economy is closely linked with the development of the private sector and especially small and medium business, which play a key role in economic reforms implemented in Kosovo.

Developing SMBs sector in Kosovo has made progress without controversial. And operating environment was not all always friendly and favorable for this sector (UNDP Kosovo, 2015).

About 15 years after the war, we can say that SMBs sector is the trend towards stabilization and normality. stabilized.

Many indicators that immediately after the war inflate the achievements of this sector now are coming and are

Inclinations for the benefit of entrepreneurs and fast are easy gradually being replaced with attitudes substantial and realistic expectations supported primarily on market developments dominated by the offer and demand.

In the early 90 s until now SMBs in Kosovo had a big burst of development.

Although the birth and development of these enterprises has been developed in an unfavorable time, a large number of these companies have managed to survive.

The strategic importance of small and medium business for the development of Kosovo's economy can be summarized in the following points:

$\square$ In Kosovo, in 1991 he had a small number of private enterprises and in 2013 were over 60 thousand registered businesses of which $98 \%$ are small to medium sized businesses and micro businesses. Registration procedures are among the easiest, the cheapest and fastest in the Balkans region.

This dynamic is an indication of entrepreneurial spirit of the people of Kosovo;

$\square$ 95\% of businesses employ fewer than 10 people. For this reason it can be said that the structure of enterprises in Kosovo is characterized by micro businesses. (Kosovo, 2012));

$\square$ Currently SMBs sector constitutes greatest absorber of labor force SMBs account for about $65 \%$ of jobs;

$\square$ The contribution of this sector (SMEs) in creating GDP is about 80\% of GDP and constitutes SMBs.

Despite the importance of SMBs, unfortunately, the capacities of these businesses are not satisfying consequence:

$\square$ Low capital base; 
$\square$ High interest rates credits;

$\square$ Not local competition;

$\square$ Political, non-stimulating fiscal and customs;

$\square$ Lack of working space and accompanying infrastructure;

$\square$ Lack of legislation and implementing mechanisms;

$\square$ Lack of electricity energy;

$\square$ Low levels of qualifications and low capacity level consulting, training, educational and business service providers and network supporting SMEs, etc.

The opening of new businesses and those extinguished since 2008- 2012

From 2008 to 2011 we have a figure roughly the same to opening new businesses in Kosovo about 7667, while in 2012 this figure increased to 9,592 businesses. While businesses which are terminated each year since 2008- 2012 have an average of 1,089 per year (Kosovo, 2012).

Table 1. New business and exhausted by 2008- 2012

\begin{tabular}{ccc}
\hline Years & Numbers of new business & Number of exhausted \\
\hline 2008 & 7557 & 943 \\
2009 & 7505 & 1136 \\
2010 & 7729 & 1363 \\
2011 & 7879 & 924 \\
2012 & 9592 & 1081 \\
\hline
\end{tabular}

Sources: Statistical Office of Kosovo

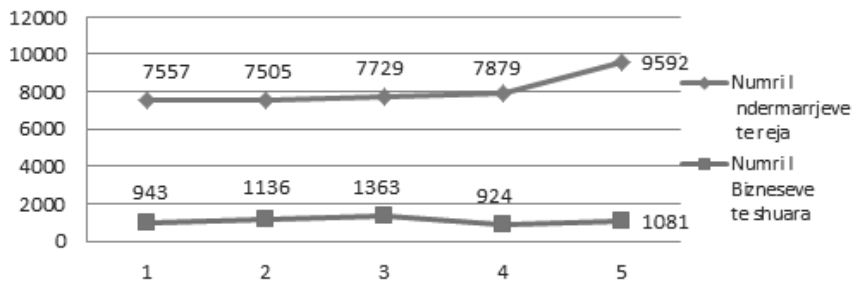

Chart 1. New businesses and exhausted by 2008-2012

This result shows that Kosovo entrepreneurs have good will towards the opening of new businesses and towards the development of existing businesses trying always to contribute to raising the quality of work and economic development of the country.

\section{Forms of Business Organization and Management}

Business is the way organizing of the activity, with the aim of making a profit for supplying people with goods and services that they need. They exist to create value for the owners, respectively their shareholders.

To establish a business enterprise, the owners decide through appropriate forms of organization and employ the managers to manage the resources that are available to the enterprise through various investments or crediting.

Forms of business organization to realize his goals are: individual businesses or businesses with a proprietor, partnership and corporations (DHAMO).

The way business management depends directly on the form of organization of the firm. So the firms in business organized as individual business, mainly the owner himself manages his own company, while the firms in the form joint ownership management of the firm appears easier for the owners of the enterprise except their capital even join their skills professional and managerial, that helps and facilitates the management of the firm enough (Besnik A. Krasniqi \& all, 2005).

Enterprises organized in the form of joint stock companies' ownership and management of the firm's capital is divided and opportunities for a better quality management of businesses are much larger. 


\section{Small and Medium Business and their Role in the Creation of New Jobs}

It pointed out that small and medium business have a higher rate of creation and bankruptcy, which is reflected in the number of new work and the removal of a certain number of employees.

In general it estimated that the number of new jobs created by small businesses is greater than the number shortened as a result of the bankruptcy of small businesses, and therefore the net creation of jobs is positive.

Contrary to the fact, the unemployment level in Kosovo is still very high. This should be a factor of motivation booster and attention to Kosovo businesses, to create conditions and to motivate young entrepreneurs to open new businesses by affecting the increase in the number of employees and increased state revenue.

To improve this situation in the fast steps the government should provide conditions for foreign investments as one of the most important ways that can decrease unemployment in certain regions of the country depending on where investments (Kristo, 2004).

\section{Challenges for the Development of Small and Medium Businesses in Kosovo}

The SME sector is not sufficiently developed in Kosovo, despite the importance of this sector.

Although differences exist from the region, some obstacles to SME development are common to the entire region and countries of EU criterion.

In many countries economic structure is oriented towards large enterprises, state-owned enterprises or large private enterprises from the energy sector, mining, food industry, tourism or real estate.

Small and medium enterprises in the country supplying the products and services low layer and medium economy and their productivity usually are poor. In many sectors of the economy, the opportunities for SMEs to enter the market are limited due to monopolistic market structures, which inhibit the activities of companies.

The small size of the SME sector in especially the owe a fact, that the challenges the region faced at the same time are the factors that create barriers to entry into the market, as well as for the development of SMEs.

In general, the SME environment is unfavorable to business.

Access to sources of financing (including credits) is one of the main constraints on the creation, survival and growth of SMEs, especially the in the case of those companies that are innovative, of high as interest rates and unfavorable to businesses. Another challenge relates to public administration, with officials, which often are not well prepared for the job, with excessive administrative fees and lack of transparency.

Additionally, insufficient quality of main infrastructure, such as roads, telecommunications and distribution networks of electricity and water, reduces the productivity of private investment for projects that depend on these infrastructures.

Economic and financial crisis further exacerbates the difficulties for SMEs, because on one side, it is difficult to find sources of financing, and on the other the demand for goods and services falls dramatically.

In general, SMEs are more volatile in time of crisis for several reasons:

1. The first reason is that they cannot easily be reduced because they are small;

2. The second reason is that they have less solid financial structure and suffer the consequences of difficulties crossing large enterprises.

\section{Conclusions and Recommendations}

At the conclusion of this paper that deals with the development of small and medium enterprises in Kosovo, i will give some recommendations, which I think a little bit will contribute to further development of these enterprises and also in economic development country.

During interviews with some of the managers of successful new businesses and those that are faded, some of the factors that most often not identified as a barrier for SMB capacity utilization are:

Unfair competition, lack of funding, the high rate of interest, not the stability of the economy, the lack of market for the sale of products and services, the high price of raw materials, lack of adequate technology, and lack of personnel qualified.

Recommendations for greater use of capacity on the BVM and rapid economic development of the country are that:

$\square$ Should eliminate unfair competition by strengthening the laws of the government, the monetary and financial policies implemented stimulus shortages financial softens circulation, and related free trade agreements with countries in 
the region and wider;

$\square$ Macroeconomic policies supported quality production and service enterprises in the country so that the market to be supplied by local production and service companies, which will improve the balance of trade exchanges with the world and the balance of payments with the world.

$\square$ To increase exports of local products in foreign markets, it is preferable to apply certain forms of stimulation of exports by the government, eliminate bureaucratic obstacles, to reduce customs duties, enhanced with methods of communication, to ensure greater information and more quality to foreign markets, eliminate difficulties for payments in the world, to improve the quality of the road network and transportation arranged more functional and more economical, and certainly increase the quality of local products and services;

$\square$ To stimulate the organization of enterprises in the form of joint stock companies (corporations) as the optimal form, which affects the investment even smaller amounts of financial funds that hold individuals and families, and at the same time will help to finance projects that cannot be financed from its own resources and bank loans;

$\square$ To stimulate SME membership in business associations, because it constitutes an important factor for the development of SME activity in Kosovo;

$\square$ Build capacities of professional staff, this implies training the staff from these small and medium business, and it is known that these businesses have staff and development strategy, but think that the training of staff in the form of potential energy continually produce increasing the capacity of the enterprise.

\section{References}

Besnik A. Krasniqi \& all. (2005). Research for SMEs. Prishtinë: Kosovo Business Consulting Group (KBCG).

DHAMO, S. Kontabiliteti Financiar. Tiranë.

KËRÇINI, D. (2008). Sipërmarrja dhe drejtimi i biznesit të vogël. Tiranë: Maluka.

Kosovo, S. O. (2012). Statistical Repertoire of Enterprises in Kosovo. Prishtinë: Statistical Office of Kosovo.

Kristo, I. (2004). Biznesi Ndërkombetar. Tiranë: Pegi.

Scribd.com. (2015, May 20). Retrieved May 20, 2015, from Scribd.com: http://www.scribd.com/doc/20134657/Biznesi-i-Vogel-Dhe-iMesem-Testi-1-Dhe-2

UNDP Kosovo. (2015, May 15). Retrieved May 15, 2015, from UNDP: http://www.ks.undp.org/

Prof. Ass. Dr. Hamdi HOTI, PhDc. Remzi AHMETI, PhDc. Rifat HOXHA "The economy of knowledge and contemporary business in Kosovo" Inertantional Scientific Journal, Scientific Center for Research and Development, No. 7 year 2015, ISSN 02-03 April Ulqin;

Prof. Ass. Dr. Hamdi HOTI, Prof. Ass. Dr. Bekim BERISHA: "The process of integration of Kosovo SME-s in the EU" International Scientific Journal DISKUTIME, no. 15 february 2015 www.diskutime.org ISSN, PRINT 1857-825X, ISSN 1857- 8543. Online;

Prof. Ass. Dr. Hamdi HOTI, Prof. Ass. Dr. Bekim BERISHA: "The role and importance of direct foreign investments in economic development of Kosovo". International Scientific Journal DISKUTIME, no. 14-November 2014 www.diskutime.org ISSN, PRINT 1857-825X, ISSN 1857- 8543. Online; 
